Biol. Neonate 1982;41:I-IV

\title{
Contents, Vol. 41, 1982
}

No. 1-2 The Effect of 3,5,3'-Triiodothyronine on Phosphoenolpyruvate Carboxykinase, Fatty Acid

Synthetase and Malic Enzyme Activity of Liver and Brown Fat of Fetal and Neonatal Rats

Hahn, P.; Hassanali, S 1

The Comparative Hemodynamic Effects of Propranolol in Chronically Instrumented Puppies and Adult Dogs

Driscoll, D.J.; Fukushige, J.; Lewis, R.M.; Hartley, C.J.; Entman, MJ

Intrauterine Growth Retardation and Development of Endocrine Pancreas in the Experimental Rat

De Prins, F.A.; Van Assche, F.A 16

Levels of Serum Protease Inhibitors during Fetal and Postnatal Development of the Pig

Weström, B.R.; Karlsson, B.W.; Svendsen, J 22

Pituitary and Adrenal Glands in Neonatal Rats Studied by Metopirone (Su4885)

Milkovic, K.; Peruzovic, M.; Paunovic, J 32

Kemicterus at Low Levels of Serum Bilirubin: The Impact of Bilirubin Albumin-Binding Capacity. A 10-Year Retrospective Survey

Pledger, D.R.; Scott, J.M.; Belfield, A 38

The Effect of Preweaning Undernutrition upon the Sexual Development of Male Mice

Jean-Faucher, C; Berger, M.; Turckheim, M. de; Veyssière, G.; Jean, C 45

9-Methyl Pteroylglutamic Acid, a Synthetic Analogue of Folic Acid: Its Effects on Hexosamine Levels in Fetal Rat Limbs and Other Fetal Tissues

Schmidt, R.R.; Abbott, P.K.; Cotler, J.M 52

Plasma Amino Acid Patterns, One and Two Hours after Continuous Naso-Gastric Alimentation of Low Birth Weight Infants Fed Two Types of Milk during the First Month of

Life

Pardou, A.; Vuye, A.; Vis, H.L

Postnatal Surges in Plasma Gut Hormones in Term and Preterm Infants

Lucas, A.; Bloom, S.R.; Aynsley-Green, A 63

Distribution of Nutrients between Fetal Brain and Body during Rat Development

Zamenhof, S.; Marthens, E. van 68

Expiratory Patterns during Sleep in Normal Full-Term and Premature Neonates

Radvanyi-Bouvet, M.F.; Monset-Couchard, M.; Morel-Kahn, F.; Vicente, G.; Dreyfus-

Brisac, C 74

Proteolytic Activity as a Regulator of the Transmission of Orally Fed Proteins from the Gut

to the Blood Serum in the Suckling Rat

Telemo, E.; Weström, B.R.; Karlsson, B.W 85

Fetal and Early Postnatal Development of Adenylate Cyclase and Cyclic AMP Phospho-

diesterase Activities in Rat Brain 
Salinas, M.; Galán, A.; Herrera, E 94

Contents

III

No. 3-4 Parathyrin and Calcium Homeostasis in the Fetus

Wadsworth, J.C.; Kronfeld, D.S.; Ramberg, C.F., Jr 101

Development of Bile Acid Biogenesis in the Rat: Effect of Neonatal Thyroidectomy, Adrenalectomy, and Streptozotocin-Induced Diabetes

Hassan, A.S.; Yunker, R.L.; Ravi Subbiah, M.T 110

Plasma Catecholamine Responses to Hypoxemia in Fetal Lambs

Lewis, A.B.; Evans, W.N.; Sischo, W 115

Ontogeny of Cyclic Nucleotides in Embryonic Chick Gonads

Teng, C 123

Supply and Release of Storage Neutrophils. A Developmental Study

Erdman, S.H.; Christensen, R.D.; Bradley, P.P.; Rothstein, G 132

Influence of a Low Protein Diet on Salicylate-Induced Damage in Mice

Eriksson, M.; Larsson, K.S 138

Plasma Corticosterone during Perinatal Period in Postmature Rats

Roudier, M.; Portha, B.; Picon, L 143

Uptake and Retention of Sex Steroids by the Neonatal Rat Adrenal Gland

Simmons, J.E.; Bronsky, P.T.; Woodard, EJ 148

Blood and Tissue Levels of Lipoperoxides in Rats during Development

Yoshioka, T.; Mori, M.; Takehara, Y.; Shimatani, M 155

Erythrocyte Enzymes in Sheep: Comparison of Activity in Fetal, Newborn, Maternal and

Nonpregnant Ewe Erythrocytes

Noble, N.A.; Cabalum, T.C.; Nathanielsz, P.W.; Tanaka, K.R

161

Changes in the Cellular Environment of Differentiating Type II Pneumocytes. Quantitative

Study in the Perinatal Rat Lung

Marin, L; Dameron, F.; Relier, J.P 172

Effect of Acute Perinatal Asphyxia on Development of the Lung and Brain in the Rat

Zhukova, T.P.; Hallman, M 183

Exposure of Rats to Lead Nitrate in Utero or Postpartum, Effects on Morphology and

Behavior

Minsker, D.H.; Moskalski, N.; Peter, C.P.; Robertson, R.T.; Bokelman, D.L

Blood Glucose of Mother and Fetus during Late Pregnancy of Rats with a Glycogen Storage

Disorder

Watts, C; Gain, K.; Malthus, R 204

No. 5-6 Accurate Measurement of Cerebral Metabolism in the Conscious, Unrestrained Neonatal

Piglet. I. Blood Flow

Wootton, R.; Flecknell, P.A.; John, M 209

Accurate Measurement of Cerebral Metabolism in the Conscious, Unrestrained Neonatal

Piglet. II. Glucose and Oxygen Utilization

Flecknell, P.A.; Wootton, R.; John, M 221

Development of Enzymes of Adenine Nucleotide Metabolism in Rat Brain and Liver

Andres, A.; Machado, A 227

Onset of a Feedback Inhibition by Testosterone in Male Rat Fetuses

Naessany, S.; Picon, R 234 
Interrelationship of Insulin and Somatomedin Activity in Fetal Rats

Heinze, E.; Nguyen Thi, C; Vetter, U.; Fussgänger, R.D 240

IV

Contents

Effects of Thyroxine on the Transmission of Immunoglobulin across the Small Intestine of

Young Rats

Jones, R.E 246

Effects of Fat-Free Diet on Fetal and Maternal Glucose-6-Phosphate Dehydrogenase and the

Timing of Parturition in the Mouse

Dresser, B.L.; Russell, P.T.; Ludwick, T.M 252

Age-Related Difference in Cerebral Perfusion Pressure Response to Acute Hypoxia in Neonatal Puppies

Raju, T.N.K.; Bhat, R.; Vidyasagar, D 258

Role of Milk-Borne Factors in Weaning and Intestinal Development

Henning, SJ 265

Proteins, Vitamin A, Carotene, Folacin, Ferritin and Zinc in Navajo Maternal and Cord

Blood

Butte, N.F.; Calloway, D.H 273

Evaluation of Renal Function in Neonatal Rats

Kavlock, R.J.; Gray, J.A 279

Pulmonary Excretion Rates of Carbon Monoxide Using a Modified Technique: Differences

between Premature and Full-Term Infants

Cohen, R.S.; Ostrander, C.R.; Cowan, B.E.; Stevens, G.B.; Hopper, A.O.; Stevenson,

D.K 289

Relationship of Plasma Total Bilirubin, Apparent Unbound Bilirubin and Total Albumin

with Cerebellar Glycogen and Abnormal Purkinje Cells in the Gunn Rat

Karp, W.B.; Moore, P.J.; Subramanyam, S.B.; Brown, D.B 294

Author Index 305

Subject Index 306

S. Karger $\square$ Medical and Scientific Publishers $\cdot$ Basel $\cdot$ München $\cdot$ Paris $\cdot$ London $\cdot$ New York

Tokyo $\square$ Sydney

Drug Dosage

The authors and the publisher have exerted every effort to ensure that drug selection and dosage set forth in this text are in accord with current recommendations and practice at the time of publication. However, in view of ongoing research, changes in government regulations, and the constant flow of information relating to drug therapy and drug reactions, the reader is urged to check the package insert for each drug for any change in indications and dosage and for added warnings and precautions. This is particularly important when the recommended agent is a new and/or infrequently employed drug.

All rights reserved.

No part of this publication may be translated into other languages, reproduced or utilized in any form or by any means, electronic or mechanical, including photocopying, recording, microcopying, or by any information storage and retrieval system, without permission in writing from the publisher.

S. Karger AG, P.O. Box, CH-4009 Basel (Switzerland) Printed in Switzerland by Thür AG Offsetdruck, Pratteln 